\title{
ADVANCES IN BASIC AND CLINICAL IMMUNOLOGY 2011
}

\author{
Javier Chinen, MD, PhD and William T. Shearer, MD, PhD \\ Allergy and Immunology Section, Department of Pediatrics, Baylor College of Medicine, Texas \\ Children's Hospital, Houston, Texas
}

\begin{abstract}
Investigations of basic immunological mechanisms and clinical studies of primary immunodeficiencies were most prevalent in 2011. Significant progress was achieved in the characterization of TH17 cells differentiation and their associated cytokines in the setting of inflammatory disorders, HIV infection and immunodysregulation disorders. The role of TACI mutations in the pathogenesis of CVID was further described and reported to be likely mediated by impaired TACI expression affecting B cell function. The frequency of autoimmunity in partial DiGeorge syndrome was estimated at $8.5 \%$, predominantly resulting in blood cytopenias and hypothyroidism. Several reports emphasized the presentation of neoplasias, most often lymphomas, as the first manifestation of several primary immunodeficiencies. Novel strategies for newborn screening of B cell lymphopenia by measuring immunoglobulin $\mathrm{K}$ chain deletion recombinant excision circles (KRECs) and for adenosine deaminase deficiency using tandem mass spectrometry were demonstrated to be feasible at large scale. Progress in the treatment of primary immunodeficiencies included increased success using unrelated HLA-compatible donors for hematopoietic stem cell transplantation, and the development of new gene therapy approaches providing with increased safety features. Induced pluripotent stem cells were developed from patients with primary immunodeficiencies, providing with a virtually unlimited resource for pathophysiology and gene correction studies. New findings in several of the uncommon immunodeficiencies, such as the increased susceptibility to severe viral infections secondary to defects in the activation of the toll-like receptor 3 pathway, overall contributed to the understanding of their immunological basis and provided for the design of effective diagnostic and therapeutic strategies.
\end{abstract}

\section{Keywords}

Immunology; primary immunodeficiencies; IVIG; TACI; CVID; cell immunity; SCID; newborn screening

This Advances article reviews the research work in the areas of basic and clinical
immunology published in the Journal from January to December 2011. (Table I)
Contributions investigating the immunological basis of inherited immunodeficiencies has
led to an exponential increase in our understanding of human molecular and immunological

C) 2011 American Academy of Allergy, Asthma and Immunology. Published by Mosby, Inc. All rights reserved. Mail correspondence to: William T. Shearer, MD, PhD, Allergy and Immunology, Texas Children's Hospital, 1102 Bates St. FC 330.01, Houston TX 77030, Phone: 832-824-1319, FAX: 832-825-1260, wtsheare@ texaschildrenshospital.org.

Publisher's Disclaimer: This is a PDF file of an unedited manuscript that has been accepted for publication. As a service to our customers we are providing this early version of the manuscript. The manuscript will undergo copyediting, typesetting, and review of the resulting proof before it is published in its final citable form. Please note that during the production process errors may be discovered which could affect the content, and all legal disclaimers that apply to the journal pertain. 
mechanisms of disease, and provided conceptual basis for the design of specific diagnostic and therapeutic interventions.

\section{Cytokines}

Akdis and coauthors ${ }^{1}$ reviewed the current understanding of the immunological actions of interleukins (IL) 1 to 37, and interferon- $\gamma$. Their role in the pathogenesis of different diseases was discussed within the context of their modulatory role in the inflammatory response, as well as their function against infectious agents. The cytokines were classified in the seven following groups: IL-1 family, common $\gamma$-chain cytokine family, IL-10 family, IL-12 family, TH2-like cytokines, interleukins with chemokine activity, and other cytokines. The authors predicted that many more new cytokines would be characterized as interleukins or chemokines. Some of the recently described cytokines have helped to explain the pathogenesis of diseases such as Behcet disease (BD). TH17 cell responses, but not TH1 responses, were found increased in $\mathrm{BD}$ patients with active disease ${ }^{2}$ and were associated with high expression of IL-21, suggesting a possible causative role of this cytokine for BD. One example of the complex interaction of interleukins was provided by Newcomb et al. ${ }^{3}$ They observed that IL-13 downregulated murine TH17 T cell differentiation and showed that human TH17 T cells expressed IL-13 $\alpha$, which mediated inhibition of IL17A production. The authors suggested that strategies targeting IL-13 effects for asthma and allergic diseases might increase TH17 responses.

\section{HIV infection}

Research in HIV pathogenesis continued to reveal new aspects of human immunology. Clark and collaborators ${ }^{4}$ showed that the number and frequency of TH1/TH17 CD4 T cells were reduced in HIV-infected patients and were only partially reconstituted with antiretroviral treatment, indicating a possible contributing factor to the increased prevalence of allergic disease in this patient population. Also in these patients, Pallikuth et al. ${ }^{5}$ reported that increases in memory B cell frequencies and in serum levels of B-cell activating factor (BAFF) and a proliferation inducing ligand (APRIL) were associated with good antibody titers against influenza vaccine, suggesting that there was a threshold of B cell function necessary to produce specific antibody responses. Of interest, Pescovitz and collaborators 6 studied the antibody responses during B-cell depletion in patients with autoimmune diabetes who received four weekly doses of Rituximab. Titers of specific antibodies to routine childhood immunizations were not different in B-cell depleted patients and normal controls, likely due to persistence of CD20-negative memory B cells and plasma cells. In contrast, attempts to induce new antibody responses during the $\mathrm{B}$ cell lymphopenia stage using the Hepatitis A vaccine or the neonatigen $\varphi$ X174 were not successful.

\section{Immunomodulatory mechanisms}

Johansen et al. ${ }^{7}$ investigated the immunomodulatory properties of clemastine, a histamine receptor 1 (H1R)-specific antagonist, using a mouse model of Listeria spp infection. They found an increased mortality due to infection in those mice that received $100 \mu \mathrm{g}$ of clemastine daily. This dose is about a hundred times the equivalent therapeutic dose in humans. Similar increases of Listeria spp in the spleen were obtained using $100 \mu \mathrm{g}$ of clemastine or desloratadine, but not cetirizine or dimetindene. The authors also showed that clemastine induced less expression of the pro-inflammatory cytokines IL- 6 and TNF- $\alpha$ in mice and human cells exposed to lipopolysaccharide. Interestingly, the effect of clemastine in Listeria-induced mortality of H1R knock-out mice and wild-type mice were not different, suggesting that the immunosuppressive effect was not H1R-dependent. 
The deleterious influence of pollution in immunity and susceptibility to infections was noted to contribute to the increased frequency of respiratory infections in urban areas. Mushtaq and collaborators ${ }^{8}$ reported that particulate matter induced increased bacterial adhesion to human airway epithelial cells, potentially explaining the association with infections. They also demonstrated that this observation was mediated by the platelet activating factor receptor (PAFR), since bacterial adhesion could be inhibited by a PAFR blocker. deRoock and coauthors ${ }^{9}$ suggested that the increased tolerogenic immune responses observed in newborns might be related to the increased expression of the receptor programmed death 1 (PD-1) in newborn CD4 T cells, which induced regulatory T cells twice as efficiently as adult cells. Paccani et al. ${ }^{10}$ showed strong induction of TH17 cell differentiation when CD4 $\mathrm{T}$ cells were exposed to the adenylate cyclase toxin of Bacillus antracis and hypothesized that this function contributes to the generation of robust memory immunity, of importance for the design of vaccines.

\section{Immunology of primary immunodeficiencies}

An increase of TH17 cells in patients with immunodysregulation, polyendocrinopathy, enteropathy, X-linked (IPEX) was demonstrated by Paserini et al. ${ }^{11}$ who also pointed out that dysfunctional, epigenetically-imprinted regulatory $\mathrm{T}$ cells were present and might contribute to the inflammatory manifestations of this condition. Papinazath et al. ${ }^{12}$ studied thymocyte development in in a mouse model of purine nucleoside phosphorylase (PNP) deficiency, and reported on the essential role of this enzyme in the survival of double positive thymocytes, which underwent apoptosis when exposed to deoxyguanosine. T cell proliferation and TCR diversity were not affected, and the restoration of PNP prevented the observed apoptosis.

Considering the potential role of matrix metalloproteinases (MM) in the development of pneumatoceles and aneurysms and the presence of STAT3 binding sites in promoter regions of genes encoding these enzymes, plasma levels of these enzymes were investigated in HyperIgE syndrome (HIES) patients. ${ }^{13}$ The levels of MM8 and MM9 were found to be increased, along with decreased expression of MM3 in HIES patients compared to controls, suggesting a possible pathogenetic mechanism.

\section{Transmembrane activator and calcium modulator and cyclophilin ligand interactor (TACl)}

Several studies aimed to clarify the role of TACI mutations in the development of common variable immunodeficiency (CVID). Bachelli et al. ${ }^{14}$ demonstrated that the mouse mutation C76R, corresponding to the common TACI mutation in humans C104R, significantly alters $\mathrm{B}$ cell function both in vitro and in vivo. Knock-in mice harboring this gene mutation in one allele and wild-type $T A C I$ in the other allele showed marginal zone B cell expansion, decreased antibody production, and splenomegaly. The authors postulate that this is likely the result of gene haploinsufficiency, because these mice presented with reduced TACI expression, and suggested that genetic or environmental modifiers determined the penetrance of this gene defect. The work of Ozcan and collaborators ${ }^{15}$ supported this concept, by showing in both human and murine cells that TACI synergizes with toll-like receptor (TLR)-9 stimulation and CD40 signaling in the activation of class-switch recombination, B cell proliferation, and subsequent B cell differentiation into plasma cells. Fried et al. ${ }^{16}$ tested the in vitro expression and function of 10 common deleterious TACI mutations that have been associated with CVID. Mutations that affected TACI binding or signaling did not have a dominant negative effect. The hypothesis of impairment of B cell function by $T A C I$ gene mutations caused by haploinsufficiency was further supported by the study of patients with Smith-Magenis syndrome (SMS) by Chinen and collaborators. ${ }^{17}$ SMS 
patients present with a heterozygous microdeletion in chromosome 18 that includes the TACI gene in most cases. In this study, TACI intra- and extra-cellular expression from the remaining allele was variable and correlated with the degree of B cell activation and ability to develop antibodies to pneumococcal polysaccharides.

\section{Inflammatory disorders and use of IVIG}

Yildirim-Toruner and Diamond ${ }^{18}$ reviewed the therapeutic armamentarium for the treatment of systemic lupus erythematous, dividing the treatment agents in four categories: treatment directed to systemic inflammation, B cell targeted antibodies, anti-cytokine antibodies and therapies targeting co-stimulatory signaling. The first category include medications that have been used for the past 30 years such as anti-malarial drugs, corticosteroids, cyclophosphamide, mycophenylate, azathioprine, and methotrexate. The new categories agents are still experimental, such as therapeutic antibodies to deplete B cells or to inhibit costimulatory molecules. Few trials in human patients have been conducted with these agents, and more data are needed to establish the safety and efficacy of these novel treatments.

A lung-specific inflammatory condition caused by exposure to beryllium (Be) was studied by Martin et al. ${ }^{19}$ Measurement of Be-specific, IFN- $\gamma$ producing CD4 T cells was used to determine sensitization to Be in 260 workers from a Be-machining facility and shown to be of predictive value for development of chronic beryllium disease.

The immunological mechanisms that support the efficacy of intravenous immunoglobulins (IVIG) in inflammatory disorders were reviewed by Ballow. ${ }^{20}$ IVIG modulates immune effector pathways mainly by blocking Fc receptor signals and modulating $\mathrm{T}$ and $\mathrm{B}$ cell function. Srehsta and collaborators ${ }^{21}$ asked if polymophisms in the FCGR2B gene, encoding the Fc $\gamma$ RIIb inhibitory receptor, might be associated with the response to IVIG in patients with Kawasaki disease. The authors found that one allele of 3 SNPs studied (A at FCGR2B $-120 \mathrm{~T} / \mathrm{a}$ ), located in the gene promoter region, was absent in patients of Asian and African descent and its presence was indeed associated with IVIG responses, adding to the evidence supporting the role of Fc $\gamma$ RIIb in the anti-inflammatory mechanisms of IVIG. Chua et al. ${ }^{22}$ confirmed the direct relationship between titers of anti-pneumococcal, anti-hemophilus and anti-tetanus IgG antibodies and total IgG serum levels in patients with hypogammaglobulinemia receiving IVIG.

The association of anti-IgA antibodies and occurrence of adverse reactions to IVIG was studied by Rachid and collaborators. ${ }^{23}$ They found 35 patients presenting with undetectable serum IgA after screening 425 immunodeficiency patients receiving IVIG, and reviewed their medical records. There were only mild adverse events secondary to IVIG administration. Three of the 35 patients had high levels of anti-IgA IgG, and only one of them developed an anaphylactic reaction to an IVIG product, which contained less than 10 $\mathrm{ug} / \mathrm{mL}$ IgA. Maddur et al. ${ }^{24}$ investigated the effect of IVIG in human TH17 cells in vitro, using IVIG at $25 \mathrm{mg} / \mathrm{mL}$ compared to human albumin $(10 \mathrm{mg} / \mathrm{mL})$. IVIG reduced $50 \%$ differentiation and proliferation of TH17 cells, with decreased expression of their most significant transcription factor, the retinoic acid related orphan receptor $\mathrm{C}$. These experiments suggest other mechanisms for the anti-inflammatory action of IVIG.

\section{Progress in primary immunodeficiencies}

Micol and coauthors ${ }^{25}$ reviewed a French cohort of 240 patients with ataxia-telangiectasis born from 1954 to 2005 and analyzed their clinical presentation with regards to the specific mutation in the causative ATM gene. They confirmed that patients with null ATM mutations had lower life expectancy due to earlier onset of cancer, as compared with patients with 
mutations allowing ATM protein expression. In contrast, the first cause of mortality in those patients with hypomorphic ATM mutations was severe respiratory infections.

The frequency of autoimmune disroders in patients with partial DiGeorge syndrome was reviewed by Tison et al. ${ }^{26}$ in a large cohort of pediatric patients. Autoimmunity was found in 10 of 130 patients $(8.5 \%)$, a frequency similar to one previous study in a different institution. The most common autoimmune conditions were cytopenias and hypothyroidism. Children with high or normal naïve CD4 T cell counts early in childhood had a lower risk of autoimmune disease. Although primary immunodeficiencies usually present with increased susceptibility to infections, they can also present with neoplastic diseases. One of these conditions is X-linked lymphoproliferative disease (XLP-1) caused by mutations in the SH2 domain-containing gene 1A (SH2D1A). Another gene, X-linked inhibitor of apoptosis (XIAP, XLP-2), is usually mutated in XLP patients when there are not pathogenic mutations in the SH21A gene. Horn and collaborators ${ }^{27}$ presented two families with XIAP mutations not previously described and reviewed the published literature of patients with this gene defect. XLP-2 patients appeared not to have an increased risk of developing lymphoma, but rather they might present with hemophagocytic lymphohystiocytosis (HLH). Three reports illustrated the development of neoplastic disease in other primary immunodeficiencies. Newell and collegues ${ }^{28}$ reported a case of zeta-chain associated protein kinase 70 (ZAP-70) deficiency who presented with an EBV-associated lymphoma in infancy, unresponsive to chemotherapy. Slatter and coauthors ${ }^{29}$ reported two cases of IL-2R $\gamma$ deficient severe combined immunodeficiency (SCID) who presented with an intracranial Hodgkin's-like, EBV-negative lymphoma. Hodgkin's lymphoma was reported in two patients with chronic granulomatous disease ${ }^{30}$ emphasizing the notion of these neoplastic disorders also occur in innate immune deficiencies. A review of the primary immunodeficiencies known to be most associated with increased occurrence of malignancies and viral infections included the following conditions: X-linked lymphoproliferative disease (XLP), IL-2 inducible T cell kinase (ITK) deficiency, epidermodysplasia verruciformis (EV), warts, hypogammaglobulinemia, infections and myelokathexis (WHIM) syndrome, autosomal recessive hyper-IgE syndrome (AR-HIES), X-linked agammaglobulinemia (XLA) and common variable immunodeficiency (CVID). ${ }^{31}$ The authors commented that neoplastic disease in these patients are often a consequence of impaired immunological surveillance against oncogenic viruses and malignant cells. Consistent with this observation, Marashi and collaborators $^{32}$ found cytomegalovirus (CMV)-specific CD8 T cells to be increased in CVID patients with inflammatory complications compared to patients without inflammation, in addition to evidence of active CMV replication. Inflammatory disease occurred more frequently in CVID patients with evidence of CMV infection (31/43 patients) than in CMVnaive patients ( $8 / 31$ patients).

The use of current molecular biology technology to characterize genetic complex diseases such as CVID was reported by Orange et al..$^{33}$ They studied 363 patients with CVID and genotyped single nucleotide polymorphisms (SNP) genome-wide to identify possible gene defects that might cause this condition. Several gene loci were significantly associated to CVID, in agreement with the observed heterogeneity of this disease. The information obtained might be useful for gene discovery and possible insight into mechanisms of humoral immunity.

Other contributions to the understanding of primary immunodeficiencies included the report of development of glomerulonephritis in patients with CD19 deficiency, ${ }^{34}$ and the diagnosis of CVID in adult patients after herpes simplex virus encephalitis. ${ }^{35}$ These patients were not receiving immunoglobulin replacement, underscoring the importance of HSV-specific IgG in the protection against disease. A comparison of the pulmonary function of 29 CVID and 8 
with XLA patients showed an accelerated decline in those with XLA, which was partially attributed to increased years of smoking and presence of bronchiectasis. ${ }^{36}$

Hannah and Etzioni ${ }^{37}$ discussed the immunological mechanisms conferring increased susceptibility to localized fungal infections, emphasizing the recent progress in the discovery of cytokines involved in the TH17 responses. They described the monogenic diseases that include mucocutanous candidiasis in their presentation, such as those caused by deleterious mutations in AIRE (APECED), STAT3 (autosomal dominant-HIES), and caspase recruitment domain family, member 9 (CARD9) and in IL-12 deficiency. An immunodeficiency syndrome characterized by cutaneous candidiasis, CMV infection, and autoimmunity was reported to be associated with the amino acid sequence variant L412F of the Toll-like receptor 3 (TLR3) protein. ${ }^{38}$ Fourteen of 21 patients with chronic mucocutanous candidiasis were heterozygous for this variant and also showed autoimmune pancytopenia, arthritis, and vitiligo. The authors demonstrated decreased interferon production and low NFKB activation to TLR3 stimulation in cells expressing the L412F variant. The TLR3 signaling pathway was explored to understand the occurrence of severe herpes simplex encephalitis in a patient with a hypomorphic NEMO mutation. ${ }^{39}$ Interferon$\alpha$ and $-\beta$ expression in response to TLR3 agonists were reduced in cell lines with the NEMO mutation, compared to controls. These findings suggest that patients with NEMO deficiency have increased susceptibility to severe viral infections.

Immunological studies in a series of 18 patients with cartilage hair hypoplasia $(\mathrm{CHH}),{ }^{40}$ with 14 of them bearing the same genetic mutation however with different history of severe infections, showed a reduced number of naïve $\mathrm{T}$ cells and increased apoptosis of their $\mathrm{T}$ cells even in those without clinical evidence of immunodeficiency. Parameters of the B cell compartment were not different from healthy controls. Two patients with reticular dysgenesis were reported to have developed myelodysplastic syndrome after a myeloablative HLA haploidentical bone marrow transplantation resulted in mixed chimerism. ${ }^{41}$

Additional case reports showed hypogammaglobulinemia and HLH in a 3 year-old boy with mutation in the FAS gene death domain, reminding us of the heterogeneity of presentation of ALPS; ${ }^{42}$ and a hypomophic mutation in $I L 2 R G$, pD134V, was associated with CD4 T lymphopenia and increased susceptibility of infections, suggesting causality. ${ }^{43}$

\section{Newborn screening of primary immunodeficiencies}

The diagnosis of Rac2 mutation immunodeficiency as the result of neonatal screening for $\mathrm{T}$ cell lymphopenia provided additional insight in the essential role of Rac2 in lymphocyte development in addition to neutrophil function. ${ }^{44}$ Knutsen and coauthors ${ }^{45}$ offered a word of caution by reporting a child with partial DiGeorge syndrome (DGS) who had absent T cell receptor excision circle (TREC), although normal percentage of CD4CD45RA T cells, and was treated as complete DGS until 8 months of age, when his immune response measurements were no longer indicating immunodeficiency. An effort to develop a newborn screening method for B cell lymphopenia was reported by Suri and collaborators. ${ }^{46}$ They measured immunoglobulin $\kappa$ chain-deletion recombinant excision circles (KRECs) using similar methodology to the measurement of TREC. KRECs were undetectable in neonatal Guthrie cards of 8 patients with B cell lymphopenia, while detectable in 133 healthy controls. Azzari and collaborators ${ }^{47}$ presented newborn screening of adenosine deaminase (ADA) deficiency-SCID using tandem mass spectrometry to detect adenine metabolites in neonatal Guthrie cards. No false positives or indeterminate results were found after screening 12,000 newborn Guthrie cards. The authors discussed the superior cost-efficiency of this method over TREC analysis for this form of SCID. 


\section{New developments in the treatment of primary immunodeficiencies}

A potential therapeutic molecule for Wiskott-Aldrich Syndrome (WAS) was suggested by investigations of Massad et al. ${ }^{48}$ They demonstrated that a short form of the WASPinteracting peptide (WIP) stabilizes mutated WAS proteins (WASP) if these are expressed, as it occurs in X-linked thrombocytopenia (XLT) patients. The investigators assayed T and $\mathrm{B}$ cell lines bearing each one of eight WASP missense mutations in the WIP-binding region, showing WASP recovery to normal levels when exposed to WIP.

Chinn and Markert ${ }^{49}$ discussed issues involved in achieving immunological tolerance of parental parathyroid grafts when done simultaneously with allogeneic thymus transplants in complete DiGeorge syndrome patients. They suggested that matching HLA class II antigens between the thymus and parathyroid grafts might determine parathyroid graft survival and long-term functionality.

The outcomes of hematopoietic stem cell transplantation (HSCT) of 13 patients with CD3- $\delta$ deficiency treated at different centers were summarized by Marcus et al. ${ }^{50}$ Only two of 7 patients treated with HLA-mismatched related donor survived while all those who received matched grafts were alive. Kang and coauthors ${ }^{51}$ reviewed current concepts and considerations of HSCT for CGD patients. Until recently, HSCT for CGD was indicated only when an HLA-compatible sibling donor was available. Recent data suggest that HSCT using HLA-mismatched and unrelated HLA-compatible donors can be safely performed in CGD patients with survival over $95 \%$, and with resolution of infections and inflammatory complications. Other progress in CGD included the restoration of microbicidal activity against Aspergillus spp spores by neutrophils from CGD patients after gene therapy, thought to be mediated by neutrophil extracellular traps and dependent on the oxidative burst. ${ }^{52}$ The empirical use of anti-TNF- $\alpha$ inhibitors for the management of granulomatous complications in CGD was challenged by Deffert et al. ${ }^{53}$ They showed that TNF- $\alpha$ was not significantly increased in granulomas induced by intradermal injection of $\beta$-glucan in mice. The investigators also showed that the use of etanecept in this animal model of granuloma did not reduce the granuloma size, and that TNF- $\alpha$ deficient and CGD double knockout mice produced a similar inflammatory response than CGD mice, suggesting that the role of TNF$\alpha$ might be negligible. The use of anti-TNF- $\alpha$ antibodies for granulomatous diseases was similarly addressed by Moshous et al. ${ }^{54}$ in CHH patients. Four of $21 \mathrm{CHH}$ patients had cutaneous and subcutaneous granulomatous infalmmation and were treated with infliximab, resulting in partial regression in 3 cases. However, one patient developed progressive multifocal encephalopathy and subsequently died. The authors concluded that the risk of severe infection is a major concern when considering anti-TNF- $\alpha$ agents for treatment of granulomatous inflammation in immunodeficient patients. Two primary immunodeficiencies, dedicator of cytokinesis 8 (DOCK8) deficiency and an early onset form of the recently described monocyte-Bcell-NK cell deficiency, were reported to be successfully treated with myeloablative HLA-identical HSCT protocols. ${ }^{55,56}$ The outcomes of HSCT for four CVID patients with severe hematological complications were reported by Rizzi and colleagues. ${ }^{57}$ There was one mortality and a diversity of outcomes, however providing some evidence of feasibility to induce significant clinical improvement in CVID.

Pessach and Notarangelo ${ }^{58}$ summarized the achievements of gene therapy efforts for primary immunodeficiencies and highlighted current limitations for widespread use, such as insertional mutagenesis resulting in leukemia. These limitations have motivated the development of new viral vectors to increase safety, by including self-inactivating features, or using lentivirus vectors. In addition, new efforts to provide gene correction with locusspecific targeting are underway, using endonucleases, zinc finger nucleases and transposons. Pessach et al. ${ }^{59}$ presented evidence of the generation of 25 induced pluripotent stem cells 
(iPSC) obtained from fibroblasts of primary immunodeficiency patients, thus providing a source material to support the development of new therapeutic approaches. (Figure 1) Fischer et al. ${ }^{60}$ summarized the gene therapy trials conducted for ADA deficiency, X-linked SCID, and for WAS in the last 10 years, which has included more than 60 patients, who benefit with significant immunoreconstitution; however, 5 children developed leukemia and one died as a result of this therapy. The authors discussed the insights provided by these trials regarding the nature of retroviral integration in the host genome, and offered considerations for development new gene vectors. Selleri et al. ${ }^{61}$ reported $\mathrm{T}$ cell homeostasis studies in a cohort of patients with ADA-deficient SCID who were reconstituted with gene therapy and with HSCT. They showed that both new naïve T cells and peripheral $\mathrm{T}$ cell expansion contribute to $\mathrm{T}$ cell reconstitution, and suggested that accelerated immunosenescence was not occurring in these patients. Of note, Gruyembaum and collaborators $^{62}$ reported the development of an adipose tumor with incomplete correction of purine metabolism 3 years in an ADA-SCID patient after gene therapy, underscoring the limitations of hematopietic stem cell-based gene therapy for the treatment of multi-organ disease. Bosticardo et al. ${ }^{63}$ expanded on the clinical evidence supporting gene therapy for WAS, and showed reconstitution of B cell function, as well as presence of WASP in B cells of splenic marginal zone and improvement of splenic architecture in a WAS murine model.

\section{Conclusions}

This year in review witnessed an increased number of contributions investigating primary immunodeficiencies. The role of TH17 cells in inflammatory disorders, HIV infection and immunodeficiencies were further defined. New evidence were published supporting the effect of TACI mutations in the development of CVID mediated by haploinsufficiency and not by a dominant negative function. HSCT using unrelated HLA-compatible grafts has proven to be of clinical benefit in an increasing number of primary immunodeficiencies, while gene therapies continue to be developed to provide increased safety.

\section{Acknowledgments}

We acknowledge the support of NIH grants RR0188, AI082978, AI36211, AI069441, and HD052102 and the David Fund of Texas Children's Hospital.

\section{References}

1. Akdis M, Burgler S, Crameri R, Eiwegger T, Fujita H, Gomez E, et al. Interleukins from 1 to 37, and interferon- $\gamma$ : Receptors, functions and roles in diseases. J Allergy Clin Immunol. 2011; 127:701-721. [PubMed: 21377040]

2. Geri G, Terrier B, Rosenzwajg M, Wechsler B, Touzot M, Seilhean D, et al. Critical role of IL-21 in modulating Th17 and regulatory T cells in Behcet disease. J Allergy Clin Immunol. 2011; 128:65564. [PubMed: 21724243]

3. Newcomb DC, Boswell MG, Zhou W, Huckabee MM, Goleniewska K, Sevin CM, et al. Human Th17 cells express a functional IL-13 receptor and IL-13 attenuates IL-17A production. J Allergy Clin Immunol. 2011; 127:1006-13. [PubMed: 21236478]

4. Clark S, Page E, Ford T, Metcalf R, Pozniak A, Nelson M, et al. Reduced Th1/Th17 CD4 T cell numbers are associated with impaired purified protein derivative-specific cytokine responses in patients with HIV-1 infection. J Allergy Clin Immunol. 2011; 128:838-46. [PubMed: 21745684]

5. Pallikkuth S, Kathikeel SP, Silva SY, Fisch M, Pahwa R, Pahwa S. Innate immune defects correlate with failure of antibody responses to H1N1/09 vaccine in HIV-infected patients. J Allergy Clin Immunol. 2011; 128

6. Pescovitz MR, Torgerson TR, Ochs HD, Ocheltree E, Mcgee P, Krause-Steinrauf H, et al. Effect of Rituximab on human in vivo antibody immune responses. J Allergy Clin Immunol. 2011; 128 
7. Johansen P, Weiss A, Bunter A, Waeckerle-Men Y, Fettelschoss A, Odermatt B, Kundig TM. Clemastine causes immune suppression through inhibition of extracellular signal-regulated kinasedependent proinflammatory cytokines. J Allergy Clin Immunol. 2011; 128

8. Mushtaq N, Ezzatti M, Hall L, Dickson I, Kirwan M, Png KMY, et al. Adhesion of Streptococcus pneumoniae to human airway epithelial cells exposed to urban particulate matter. J Allergy Clin Immunol. 2011; 127:1236-42. [PubMed: 21247619]

9. de Roock S, Hoecks SBEA, Meurs L, Steur A, Hoekstra MO, Prakken BJ, et al. Critical role for programmed death 1 signaling and protein kinase $\mathrm{B}$ in augmented regulatory $\mathrm{T}$ cell induction in cord blood. J Allergy Clin Immunol. 2011; 128

10. Paccani SR, Benagiano M, Savino MT, Finetti F, Tonello F, D'Elios MM, Baldari CT. The adenylate cyclase of toxin of Bacillus antracis is a potent promoter of $\mathrm{TH}(17)$ development. $\mathrm{J}$ Allergy Clin Immunol. 2011; 127:1635-7. [PubMed: 21310477]

11. Paserini L, Olek S, Di Nunzio S, Federica B, Hambleton S, Abinum M, et al. Forkhead box protein 3 (FOXP3) mutations lead to increased TH17 cell numbers and regulatory T-cell instability. J Allergy Clin Immunol. 2011; 128

12. Papinazath T, Min W, Sujiththa S, Cohen A, Hackerley C, Roiffman C, Grunebaum E. Effects of purine nucleotide phosphorylase deficiency on thymocyte development. J Allergy Clin Immunol. 2011; 128:854-63. [PubMed: 21868080]

13. Sekhsaria V, Dodd LE, Hsu AP, Heimall JR, Freeman AF, Ding L, Hollands SM, Uzel G. Plasma metalloproteinase levels are dysregulated in signal transducer and activator of transcription 3 mutated hyper IgE syndrome. J Allergy Clin Immunol. 2011; 128

14. Bacchelli C, Buckland KF, Buckridge S, Salzer U, Schneider P, Thrasher AJ, Gaspar HB. The C76R transmembrane activator and calcium modulator cyclophilin ligand interactor mutation disrupts antibody production and B cell homeostasis in heterozygous and homozygous mice. $\mathrm{J}$ Allergy Clin Immunol. 2011; 127:1253-1259. [PubMed: 21458042]

15. Ozcan E, Rauter I, Garibyan L, Dillon SR, Geha RS. Toll-like receptor 9, transmembrane activator and calcium modulator cyclophilin ligand interactor, and CD40 synergize in causing B-cell activation. J Allergy Clin Immunol. 2011; 128:606-9.

16. Fried AJ, Rauter I, Dillon SR, Jabara HH, Geha RS. Functional analysis of transmembrane activator and calcium modulating cyclophilin ligand interactor (TACI) mutations associated with common variable immunodeficiency. J Allergy Clin Immunology. 2011; 128:226-8. [PubMed: 21419480]

17. Chinen J, Martinez-Gallo M, Gu W, Cols M, Cerutti A, Radigan L, et al. Transmembrane activator and CAML interactor (TACI) haploinsuffiecny results in B-cell dysfunction in patients with Smith-Magenis syndrome. J Allergy Clin Immunol. 2011; 127:1579-86. [PubMed: 21514638]

18. Yildirim-Toruner C, Diamond B. Current and novel therapeutics in the treatment of systemic lupus erythematous. J Allergy Clin Immunol. 2011; 127:303-312. [PubMed: 21281862]

19. Martin AK, Mack DG, Falta MT, Mroz MM, Newman LS, Maier LA, Fontenot AP. Berylliumspecific CD4 T cells in blood as a biomarker of disease progression. J Allergy Clin Immunol. 2011; 128:1100-6. [PubMed: 21943943]

20. Ballow M. The IgG molecule as a biological immune response modifier: Mechanisms of action of intravenous immune serum globulin in autoimmune and inflammatory disorders. J Allergy Clin Immunol. 2011; 127:315-23. [PubMed: 21185071]

21. Shreshta S, Wiener HW, Olson AK, Edberg JC, Bowles NE, Patel H, Portman MA. Functional FCGR2B gene variants influence intravenous immunoglobulin response in patients with Kawasaki disease. J Allergy Clin Immunol. 2011; 128:677-9. [PubMed: 21601260]

22. Chua I, Lagos M, Cjarambolous BM, Workman S, Chee R, Grimbacher B. Pathogen-specific IgG antibody levels in patients receiving immunoglobulin replacement do not provide additional benefit to therapeutic management over total serum IgG. J Allergy Clin Immunol. 2011; 127:1410-1. [PubMed: 21376379]

23. Rachid R, Castells M, Cunningham-Rundles C, Bonilla FA. Association of anti-IgA antibodies with adverse reactions to gamma-globulin infusion. J Allergy Clin Immunol. 2011; 128:228-9. [PubMed: 21397310] 
24. Maddur MS, Vani J, Hedge P, Lacroix-Desmazes S, Kaveru SV, Bayry J. Inhibition of differentiation, amplification and function of human TH17 cells by intravenous immunoglobulin. J Allergy Clin Immunol. 2011; 127:823-30. [PubMed: 21281961]

25. Micol R, Slama LB, Suarez F, LeMignot L, Beaute J, Mahlaoui N, et al. Morbidity and mortality from ataxia telangiectasia are associated with ATM genotype. J Allergy Clin Immunol. 2011; 128:382-9. [PubMed: 21665257]

26. Tison BE, Nicholas SK, Abramson SL, Hanson IC, Paul ME, Seeborg FO, et al. Autoimmunity in a cohort of 130 pediatric patients with partial DiGeorge syndrome. J Allergy Clin Immunol. 2011; 128

27. Horn PC, Belohradsky BH, Urban C, Weber-Mzell D, Meindl A, Schuster V. Two new families with X-linked inhibitor of apoptosis deficiency and a review of all 36 published cases. J Allergy Clin Immunol. 2011; 127:544-6. [PubMed: 21281876]

28. Newell A, Dadi H, Goldberg R, Ngan BY, Grunebaum E, Roifman CM. Diffuse large B cell lymphoma as presenting feature of Zap-70 deficiency. J Allergy Clin Immunol. 2011; 127:517-20. [PubMed: 21094993]

29. Slatter MA, Angus B, Windebank K, Taylor A, Meaney C, Lester T, et al. Polymorphous lymphoproliferative disorder with Hodgkin-like features in common g-chain-deficient severe combined immunodeficiency. J Allergy Clin Immunol. 2011; 127:533-5. [PubMed: 21094519]

30. Lugo Reyes SO, Suarez F, Herbigneaux RM, Pacquement H, Reguerre Y, Riviere JP, et al. Hodgkin lymhoma in 2 children with chronic granulomatous disease. J Allergy Clin Immunol. 2011; 127:543-4. [PubMed: 21168906]

31. Rezaei N, Hedayat M, Aghamohammadi A, Nichols KE. Primary immunodeficiency diseases associated with increased susceptibility to viral infections and malignancies. J Allergy Clin Immunol. 127:1329-41. [PubMed: 21514636]

32. Marashi SM, Raeiszadeh M, Workman S, Rahbar A, Soderberg-Naucler C, Klenerman P, et al. Inflammation in common variable immunodeficiency is associated with a distinct CD8 response to cytomegalovirus. J Allergy Clin Immunol. 2011; 127:1385-93. [PubMed: 21536322]

33. Orange JS, Glessner JT, Resnick E, Sullivan KE, Lucas M, Ferry B, et al. Genome-wide association identifies diverse causes of common variable immunodeficiency. J Allergy Clin Immunol. 201; 127:1360-1367. [PubMed: 21497890]

34. Vince N, Boutboul D, Mouillot G, Just N, Peralta M, Casanova JL, et al. Defects in the CD19 complex predispose to glomerulonephritis, as well as IgG1 subclass deficiency. J Allergy Clin Immunol. 2011; 127:538-41. [PubMed: 21159371]

35. Borish L, Ayars AG, Kirkpatrick CH. Common variable immunodeficiency presenting as herpes simplex encephalitis. J Allergy Clin Immunol. 2011; 127:541-543. [PubMed: 21167568]

36. Chen Y, Stirling RG, Paul E, Hore-Lacy F, Thompson BR, Douglass JA. Longitudinal decline in lung function in patients with primary immunoglobulin deficiencies. J Allergy Clin Immunol. 2011; 127:1414-6. [PubMed: 21546068]

37. Hanna S, Etzioni A. New host defense mechanisms against Candida species clarify the basis of clinical phenotypes. J Allergy Clin Immunol. 2011; 127:1433-7. [PubMed: 21497889]

38. Nahum A, Dadi H, Bates A, Roifman CM. The L412F variant of Toll-like receptor 3 (TLR3) is associated with cutaneous candidiasis, increases susceptibility to cytomegalovirus and autoimmunity. J Allergy Clin Immunol. 2011; 127:528-30. [PubMed: 21093032]

39. Audry M, Ciancanelli M, Yang K, Cobat A, Chang HH, Sancho-Shimizu V, et al. NEMO is a key component of NFkB and IRF3- dependent TLR3-mediated immunity to herpes simplex virus. J Allergy Clin Immunol. 2011; 128:610-7. [PubMed: 21722947]

40. De la Fuente M, Recher M, Rider NL, Staruss KA, Morton DH, Adair M, et al. Reduced thymic output, cell cycle abnormalities, and increased apoptosis of T lymphocytes in patients with cartilage-hair hypoplasia. J Allergy Clin Immunol. 2011; 128:139-46. [PubMed: 21570718]

41. Lagresle-Peyrou C, Neven B, Six E, Picard C, Demerens-deChappedelaine C, Bertrand Y, et al. Occurrence of myelodysplastic syndrome in 2 patients with reticular dysgenesis. J Allergy Clin Immunol. 2011; 128:230-1. [PubMed: 21458044] 
42. Kuijpers TW, Baars PA, aan DeKerk DJ, Jansen MH, Dors N, van Lier RAW, Pals ST. Common variable immunodeficiency and hemophagocytic features associated with FAS gene mutation. J Allergy Clin Immunol. 2011; 127:1411-4. [PubMed: 21450335]

43. Kuijpers TW, Baars PA, aa deKerk DJ, Jansen MH, Derk IA, Bredius RGM, et al. A novel mutation in CD132 causes X-CID defective T cell activation and impaired humoral reactivity. J Allergy Clin Immunol. 2011; 128

44. Accetta D, Syverson G, Bonacci B, Reddy S, Bengston C, Surfus J, et al. Human phagocyte defect caused by a Rac2 mutation detected by means of neonatal screening for T cell lymphopenia. $\mathrm{J}$ Allergy Clin Immunol. 2011; 127:535-8. [PubMed: 21167572]

45. Knutsen AP, Baker MW, Markert ML. Interpreting low T cell receptor excision circles (TRECs) in newborns with DiGeorge anomaly: importance of assessing naïve T cell markers. J Allergy Clin Immunol. 2011; 128

46. Suri D, Rawat A, Singh S, Pan-Hammarstrom Q, Hammarstrom L, Reichenbach J, et al. Quantification of k-deleting recombination excision circles in Guthrie cards for the identification of early B-cell maturation defects. J Allergy Clin Immunol. 2011; 128:223-5. [PubMed: 21397315]

47. Azzari C, laMarca G, Resti M. Neonatal screening for severe combined immunodeficiency caused by adenosine deaminase defect: a reliable and inexpensive method using tandem mass spectrometry. J Allergy Clin Immunol. 2011; 127:1394-6. [PubMed: 21624616]

48. Masaad MJ, Ramesh N, Le Bras S, Giliani S, Notarangelo LD, Al-Herz W, et al. A peptide derived from the Wiskott-Aldrich syndrome (WAS) protein level and actin cytoskeleton reorganization in lymphocytes from patients with WAS mutations that disrupt WIP binding. J Allergy Clin Immunol. 2011; 127:998-1005. [PubMed: 21376381]

49. Chinn IK, Markert ML. Induction of tolerance to parental parathryoid grafts using allogeneic thymus tissues in patients with DiGeorge anomaly. J Allergy Clin Immuno. 2011; 127:1351-55.

50. Marcus N, Takada H, Law J, Cowan MJ, Gil J, Reguiro J, et al. Hematopoietic stem cell transplantation for CD3-delta deficiency. J Allergy Clin Immunol. 2011; 128

51. Kang EM, Marciano BE, DeRavin S, Zarember KA, Holland SM, Malech HL. Chronic granulomatous disease: overview and hematopoietic stem cell transplantation. J Allergy Clin Immunol. 127:1319-26. [PubMed: 21497887]

52. Bianchi M, Niemiec MJ, Siler U, Urban CF, Reichenbach J. Restoration of anti-Aspergillus defense by neutrophil extracellular traps in chronic granulomatous disease after gene therapy is calprotectin-dependent. J Allergy Clin Immunol. 2011; 127:1243-1252. [PubMed: 21376380]

53. Deffert C, Olleros ML, Huiping Y, Hermann FR, Zekry D, Garcia I, et al. TNF- $\alpha$ blockade in chronic granulomatous disease-induced hyperinflammation:patient analysis and murine model. J Allergy Clin Immunol. 2011; 128:675-7. [PubMed: 21596423]

54. Moshous D, Meyts I, Fraitag S, Janssen CEI, Debre M, Suarez F, et al. Granulomatous inflammation in cartilage-hair hyperplasia: risks and benefits of anti-TNF-alpha mAbs. J Allergy Clin Immunol. 2011; 128:847-53. [PubMed: 21714993]

55. Barlogis V, Galambrun C, Chmabost H, Lamoreux-Toth S, Petit P, Stephan JL, et al. Successful allogeneic hematopoietic stem cells transplantation for DOCK8 deficiency. J Allergy Clin Immunol. 2011; 128:420-2. [PubMed: 21546070]

56. Cancrini C, Scarselli A, Scaramuzza S, Chiriaco M, DiCesare S, DiMatteo G, et al. Early-onset monocyte-B-natural killer dendritic cell's deficiency successfully treated with hematopoietic stem cell transplantation. J Allergy Clin Immunol. 2011; 128:897-900. [PubMed: 21868074]

57. Rizzi M, Neumann C, Fielding AK, Marks R, Goldacker S, Thaventhiran J, et al. Outcome of allogeneic stem cell transplantation in adults with common variable immunodeficiency. $\mathrm{J}$ Allergy Clin Immunol. 2011; 128

58. Pessach IM, Ordovas-Montanes J, Zhang SY, Casanova JL, Giliani S, Gennery AR, et al. Induced pluripotent stem cells: a novel frontier in the study of human primary immunodeficiencies. $\mathrm{J}$ Allergy Clin Immunol. 2011; 127:1400-7. [PubMed: 21185069]

59. Pessach IM, Notarangelo LD. Gene therapy for primary immunodeficiencies: looking ahead, toward gene correction. J Allergy Clin Immunol. 2011; 127:1344-50. [PubMed: 21440291] 
60. Fischer A, Hacein-Bey-Albina S, Cavazzana-Calvo M. Gene therapy for primary adaptive immune deficiencies. J Allergy Clin Immunol. 2011; 127:1356-59. [PubMed: 21624615]

61. Selleri S, Brigida I, Casiraghi M, Scaramuzza S, Cappelli B, Cassani B, et al. In vivo T-cell dynamics during immune reconstitution after hematopoietic stem cell gene therapy in adenosine deaminase severe combined immune deficiency. J Allergy Clin Immunol. 2011; 127:1368-75. [PubMed: 21477850]

62. Grunebaum E, Chung CTS, Dadi H, Kim P, Brigida I, Ferrua, et al. Purine metabolism, immune reconstitution and abdominal adipose tissue after gene therapy for adenosine deaminase deficiency. J Allergy Clin Immunol. 201; 127:1417-9. [PubMed: 21531016]

63. Bosticardo M, Draghici E, Schena F, Sauer AV, Fontana E, Castiello MC, et al. Lentiviralmediated gene therapy leads to improvement of B-cell functionality in a murine model of WiskottAldrich syndrome. J Allergy Clin Immunol. 2011; 127:1376-84. [PubMed: 21531013]

\section{Abbreviations}

$\begin{array}{ll}\text { APECED } & \text { autoimmunity, polyendocrinopathy, candidiasis and ectodermal dystrophy } \\ \text { CGD } & \text { chronic granulomatous disease } \\ \text { CVID } & \text { combined variable immunodeficiency } \\ \text { HHV } & \text { human herpes virus } \\ \text { HIES } & \text { Hyper IgE syndrome } \\ \text { HSCT } & \text { hematopoietic stem cell transplantation } \\ \text { IPEX } & \text { immunodeficiency, polyendocrinopathy, enteropathy X-linked } \\ \text { IVIG } & \text { intravenous immunoglobulins } \\ \text { MMP } & \text { matrix metalloproteinases } \\ \text { PAFR } & \text { platelet activating factor receptor } \\ \text { PNP } & \text { purine nucleoside phosphorylase } \\ \text { SCID } & \text { severe combined immunodeficiency } \\ \text { TACI } & \text { transmembrane activator and calcium modulator and cyclophilin ligand } \\ \text { WAS } & \text { interactor }\end{array}$




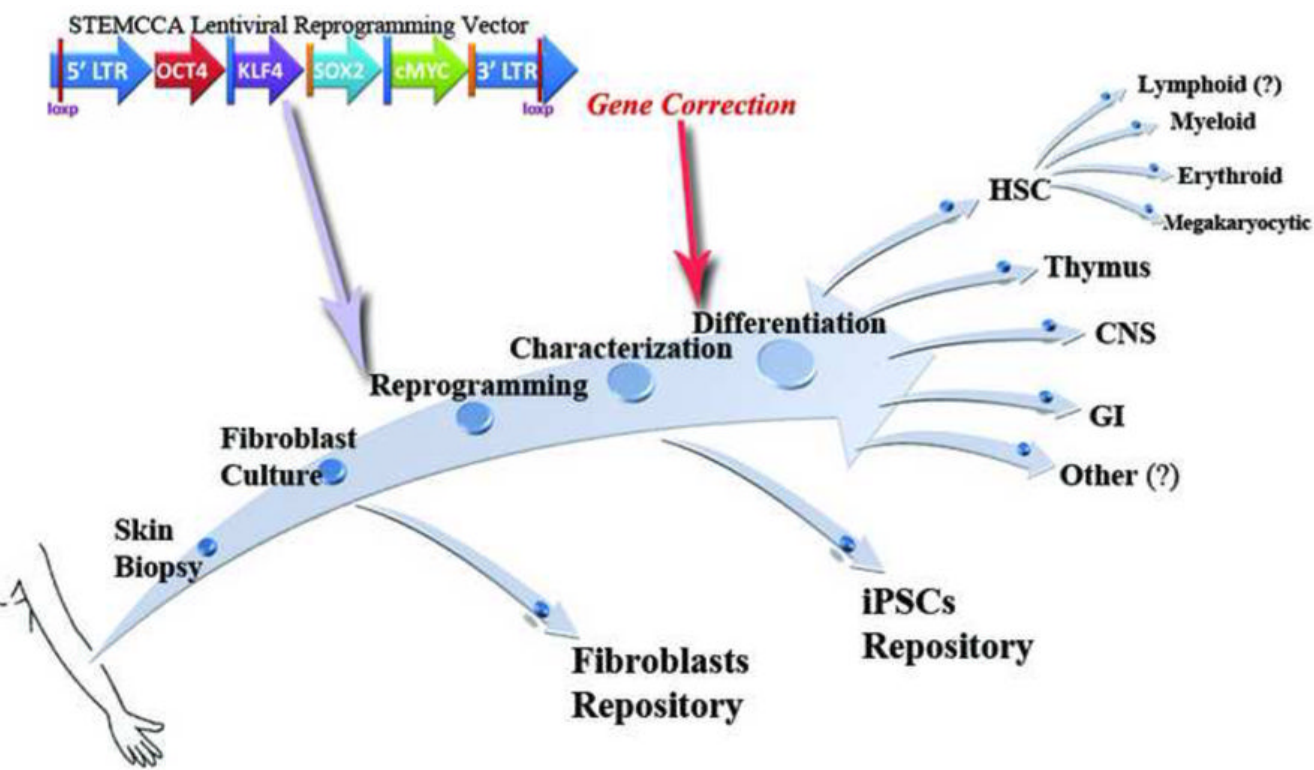

Figure 1.

Development of induced pluripotent stem cells (iPSC) and differentiation into different cell lineages. Fibroblasts are obtained from a skin biopsy and reprogrammed into iPSC by expressing 4 genes (OCT4, KLF4, SOX2, $c M Y C)$ introduced by the STEMCCA lentiviral vector. Different cell lineages can be differentiated in vitro using specific culture conditions. (Reproduced with permission from Pessach IM, Ordovas-Montanes J, Zhang SY, Casanova JL, Giliani S, Gennery AR, et al. Induced pluripotent stem cells: a novel frontier in the study of human primary immunodeficiencies. J Allergy Clin Immunol 2011; 127: 1400-7) 


\title{
Table I
}

Selected key advances in basic and clinic immunology in 2011.

\author{
TH17 cells \\ - IL-21 modulates TH17 cells in Behcet disease. \\ - $\quad$ IL-13 attenuates IL-17A production. \\ - FOXP3 mutations lead to increased TH17 cell numbers and regulatory T-cell instability. \\ - Bacillus antracis toxin promotes TH17 development \\ - IVIG inhibits TH17 cell differentiation \\ TACI \\ - The C76R TACI mutation disrupts B cell function in heterozygous and homozygous mice. \\ - TLR9, TACI and CD40 synergize in causing B-cell activation. \\ - TACI haploinsufficiency results in B-cell dysfunction in Smith-Magenis syndrome.

\section{Immunoregulation} \\ - Adhesion of pneumococci to epithelial cells increases when exposed to urban particulate matter. \\ - $\quad$ FCGR2B gene variants are associated with response to IVIG in patients with Kawasaki disease.
}

\section{Primary immunodeficiency}

- Plasma metalloproteinase levels are dysregulated in hyper IgE syndrome.

- $\quad$ XIAP most often presents with hemophagocytic lymphohystocytosis

- Frequency of autoimmunity in partial DiGeorge syndrome is $8.5 \%$

- $\quad$ NEMO deficiency phenotype includes increased susceptibility to severe viral infections

- Granulomatous disease in CVID might be associated to CMV infection

- $\quad \kappa$ recombination excision circles might be used for newborn screening of B cell lymphopenia

- Hematopoietic stem cell transplantation has been successful for patient with CD3 $\delta$ deficiency, DOCK8 deficiency and CVID

- Gene therapy for WAS restores B cell function.

- Immunoreconstitution for ADA deficiency does not result in early immunosenescence.

- Induced pluripotent stem cells for the study of human primary immunodeficiencies have been developed. 